\title{
The Impact of Social Assistance on Social Security of Elders: An Empirical Study of Elders in Matara District in Sri Lanka
}

Sri Lanka Journal of Social Sciences and Humanities Volume 1 Issue 2 August 2021: 123-133 ISSN: 2773 692X (Online), 27736911 (Print) Copyright: (C) 2021 The Author(s)

Published by Faculty of Social Sciences and Languages, Sabaragamuwa University of Sri Lanka Website: https://www.sab.ac.lk/sljssh DOI: http://doi.org/10.4038/sljssh.v1i2.44

\author{
Jayathma, H.W.T. ${ }^{1}{ }^{*}$ and Priyanath H.M.S. ${ }^{1}$ \\ ${ }^{1}$ Department of Economics and Statistics, Sabaragamuwa University of Sri Lanka, Belihuloya, 70140, Sri Lanka.
}

Received: 29 November, 2020, Revised: 15 March, 2021, Accepted: 25 May, 2021.

How to Cite this Article: Jayathma, H.W.T. and Priyanath H.M.S. (2021). The impact of social assistance on social security of elders: An empirical study of elders in Matara District in Sri Lanka. Sri Lanka Journal of Social Sciences and Humanities, 1(2), 123-133.

\begin{abstract}
This study investigates the impact of social assistance on the social security of elders in Sri Lanka applying the convergent parallel mixed method. The quantitative data collected from 149 elders in both formal and informal sectors in the Matara District. A structured questionnaire was used to gather data and the Partial Least Square Structural Equation (PLS-SEM) model was employed to analyze data. Qualitative data were gathered having the face-to-face interviews with six elders and analyzed employing qualitative content analysis. The study revealed that formal social assistance had the highest positive impact on the social security of elders in the formal sector while it was not significant with the informal sector elders. However, formal social assistance was significant in both sectors under qualitative content analysis. Informal social assistance was evaluated using four major dimensions; social network, social connectedness, economic support during the emergency condition, health care support. Among these dimensions, social security during emergency conditions had significance in both sectors, and health care support positively significant in the formal sector. However, qualitative results confirmed that all these dimensions directly affect the increase of the social security of elders. Thus, it can be concluded that both formal and informal social assistance has an impact on the enhancement of the social security of elders in the formal sector while formal social assistance has not impacted the increase of social security of elders in the informal sector.
\end{abstract}

Keywords: Elders, Formal Social Assistance, Informal Social Assistance, Social Security

\section{INTRODUCTION}

Population aging is a universal phenomenon, Sri Lanka is also one of the fastest aging countries in the world. In Sri Lanka, 12.4 percent out of the whole population represents the elderly population, and the old-age dependency ratio records at 13.58 percent in 2018 (World Bank, 2018). The elderly population in Sri Lanka is projected to increase up to 18 percent by 2025 and 28.8 percent by 2050 (De Silva, 2012). Sri Lanka has to develop a strategy to look after the elderly group and spend more public money on social protection. In Sri Lanka, some elders have joined formal schemes while most elders have no adequate level of formal coverage of social assistance. Although formal social security scheme like Farmer's Pension scheme, Fisherman's Pension scheme, Employment Provident Fund (EPF), Employment Trust Fund (ETF), Self-Employment Pension Scheme were introduced by the government to the elderly people, those have covered a smaller number i.e. 20 percent (Arunathilake \& Jayawardena, 2010; Menike, 2015). As a result, the elders in the informal sector face a serious social protection issue and the country has given less attention to the informal care for elders. Less number of primary care schemes for elders (informal social assistance) cause a remarkable issue in Sri Lankan society (Gaminirathna, 2014).

Some scholars define traditional social networks also have been a source of social assistance to operate the informal sector (Adzawala, Baanni \& Wontumi, 2015). A great proportion of the elders in Sri Lanka depends on their children or relatives for shelter and food (Bilesha, 2011). Some scholars found that the pension scheme had caused to increase in the social security of elders in the formal sector (Adzwala et al., 2015). According to informal social assistance, respect and taking care of elders had a positive impact on the social security of elders (Bilesha, 2011). Emotional support by children, relatives, and friends is the most important informal social assistance to the social security of elders (ibid). Thilakarathene and Jayawardena (2015) said that social assistance schemes for the informal sector such as Samurdhi, Divinaguma cash transfer program, Elders assistance program, Disability assistance program were the most popular dimensions researchers used to measure informal social assistance. On the other hand, non-governmental organizations provide different kinds of informal social assistance like maintaining elders' homes, providing financial aid, providing foster care for elders, establishing daycare centers, and home care for elders (Menike, 2015). Daycare centers for elders are a very popular concept today. Because care for an elderly parent is the most important responsibility of children, as they are going out for their employment that daycare centers play an important role in the social security of elders (Menike, 2015). However, existing studies

\footnotetext{
* Corresponding author: Tel.: +94 (77) 589 8455; Email: thisuri11223jayathma@gmail.com
}

(iD) https://orcid.org/0000-0002-7450-1436 
paid lower attention to measure the informal assistance concerning the social security of elders in the informal and formal sectors. Further, it was difficult to find studies that were conducted to identify the impact of informal social assistance on elders. Hence, to fill these gaps, the study focused on identifying how social assistance (both formal and informal) affects the social security of elders. Therefore, the study attempts to explore the impact of formal and informal social assistance on the social security of elders in Sri Lanka.

\section{LITERATURE REVIEW AND HYPOTHESIS}

The dependent variable of this study was the social security of elders and the independent variables were social assistance. Independent variables are divided into two main variables as formal social assistance and informal social assistance. Social security reflects two items health care and income security. Formal social security reflects in four dimensions, government pension scheme, ETF, EPF, Fisherman's Pension Scheme, and Farmer's Pension Scheme. The purpose of this study was to identify the impact of social assistance on the social security of elders in Sri Lanka. Some scholars found pension schemes caused to increase in the social security of elders in the informal sector (Adzwala, et al., 2015). The majority of the elders were self-employed agricultural workers. But this exciting security system was insufficient to improve financial needs. Since most of these schemes were targeted at public and private sector (formal sector) employees (Perera, 2011).

Formal social assistance (FSA) and social security of elders: The welfare of people is the core responsibility of the government. Pension is synonymous with the government jobs in Sri Lanka. In the public sector, the employees receive a pension, and private sector employees have the Employee's Provident Fund (EPF) and the Employees' Trust Fund (ETF). The EPF was established in 1958 and was the largest single fund in Sri Lanka. It was administered by the Monitory Board of Central Bank of Sri Lanka (Karunarathna \& Wasana, 2002). The ETF was established in 1981 and it was administered by the ETF board and the Ministry of Labour and Vocational Training. This was the largest social security benefit for corporations, universities, and private sector enterprise employees. Public Service Pension Scheme was established in 1901. It was financed by the government budget. This Social Security benefit covered public sector employees, Government teachers, civil servants, armed services, Provincial and local government employees, and judicial officers. After retirement at the age of 55, they can get this benefit. According to Karunarathna, et al., (2002), we need more social assistance programs to fulfill the social security of every person in the country. Some scholars found that FSA was the main determinant and it was highly impacted the social security of elders. As a result that Sri Lankan scholars identify EPF, ETF, Government pension have a positive impact on the social security of elders in Sri Lanka (Jayawardena \& Arunathlake 2010; Perera 2011; Menike 2015; Perera \& Weerakkody, 2019)

Pension scheme for farmers established under Act, No 12 of 1987 was mainly targeted by the 2 million persons directly or indirectly engaged in the agriculture sector. Most farmers were working harder in youth through too late in life. But they had no sufficient plan for their old age security (Eriyagama \& Rannan-Eliya, 2003). This is the voluntary contributory scheme that is targeted to fulfill the social security of Farmers in old age. This pension scheme is administered by the Agriculture and Agrarian Insurance Board (AAIB). They estimated 10-12 lakhs of farmers were eligible for this scheme but 675,000 farmers had enrolled in this scheme (Eriyagama \& Rannan-Eliya, 2003). On the other hand, low-income workers want a premium mix of benefits for both longterm and short-term social security (Gaminirathna, 2004).

Fisherman Pension Scheme and Social Security Benefit Scheme established under Act, No 23 of 1990. It was administered by the AAIB. Mainly targeted to the 115000 workers but it covered nearly 50,000 Fishermen around the country (Eriyagama \& Rannan-Eliya, 2003). The main objective was to provide social security to fishermen when they were old or disabled and to give care for their family members even in the risky nature of their occupation. It covered both fishermen in the marine and inland fishery industry. This has specific objectives, provide social security to fisherman during old age or disability, and give protection for their families. On the other hand, the scheme provides them with pension funds and collective insurance funds. Hence this study assumes that,

\section{H1: FSA has a positive impact on the social security of el-} ders.

Social connectedness (SC) and social security: According to Zaho, Jing, Yan \& Yu (2020) SC was the main dimension of informal social care. They said that the breakdown of the SC due to urbanization may cause to weaken the kinship and friendship among the elders' community. On the other way, the low level of birth rate and death rate along with the higher level of divorce rate caused to decrease the social care for the elderly people in the community (Zaho, et al, 2020). Asanta \& Castillo (2018) revealed that SC depended on network size and satisfaction with the network. Further, they explained that it could be effected to the physical and mental health of elderly people to improve their social security under health care. Finally, they found that $\mathrm{SC}$ had a positive impact on the social security of the people. According to Emlet \& Moceri (2012), it is very important to improve the elderly-friendly communities to promote the importance of civic engagement and paid opportunities and prioritizing of the aging problem. Also, they explain SC has a positive impact on creating strong social ties to the elderly-friendly community. Finally, they identified that it should be very much significant with the creation of a social network for social security for elders (Goswami, Kobler, Leimeister \& Krcmar, 2010). As a result, SC has a positive impact on the elderly population. Hence this study assumes that;

H2: SC has a Positive Impact on the social security of elders.

Social network (SN) and social security: SN means a web of social relationships surrounded an individual and characteristic of social ties (Garcia, Banegas, Preez, Regaders, Cabrera \& Rodriguez, 2005). Further, they explained a person with whom fewer social relationships had caused increased mortality, cardiovascular disease, and suicide. When elders have a good SN they can get more benefits to solve their day-today life problems. According to Grucia, et al., (2005), SN and social support are the two different concepts and social support to mediate the role of the relationship between the SN and health. According to Pinquart \& Sorensen (2000), networks and subjective well-being in later life (social security of elders) had a positive relationship. Hence this study assumes;

\section{H3: SN has a positive impact on the social security of elders.}

Economic support during the emergency condition (ES) and social security: In the elder community they can get into a sudden illness or any other financial problem unexpectedly. So they want some financial assets to fulfill these issues. 
Sometimes they have to pawn their jewelry or get loans to fulfill that unexpected financial issues. However, if they have a good relationship with their relatives, neighbors, or friends they can get financial support from them when they are facing an unexpected situation. Hence this study assumes that;

H4: ES has a positive impact on the social security of elders.

Healthcare support (HS) and social security: In Sri Lanka poor vision, impaired hearing, cardiovascular diseases, and cancers are the main current diseases and ill health conditions among elders in Sri Lanka. In Sri Lanka geriatricians and geriatric health care shortage are severe problems of the health care of the elders in Sri Lanka (Perera, 2011). Dai (2015) said health security in old age people in China had a positive impact on the social security of elders. Further, Perera (2011) \& Dai (2015) explained that improved health care among rural areas was very much important to increase the social security of elders. Hence this study assumes that,

\section{H5: HS has a positive impact on the social security of elders}

\section{METHODOLOGY}

The convergent parallel mixed method was employed to study the research problem. Primary data were collected for this study employing a questionnaire survey. Sri Lankan elderly persons were considered as the population of the study. The study selected Matara District in the Southern Province of Sri Lanka using simple random sampling and the district was one of the higher levels of the elder population recorded. Got information from the elders through the randomly selected four Grama Niladari Divisions; Pamburana, Gandara, Welegoda, and Godagama. Data were collected through face-to-face interviews. Thus, the convenient sampling method was adopted as a data collection method for this study. Data was collected from one hundred and fortynine (149) elders age above 65 who lived in selected villages. According to the responses, 70 elders consisted of the informal sector and they got farmers or fisherman pension scheme and 79 elders consisted of formal sector pensions, $E T F$, and EPF. A structured questionnaire was used to gather data. The questionnaire items were designed systematically based on literature published in cited journals. In this research, social security was the dependent variable and it was measured through the question based on the theoretical definition given by the previous scholars, such as Thaware $\&$ Gymkhana (2017); Cousin (2017); Menike (2015); Sanita, Parida \& Pattyat (2019) and adopted Likert scale to measure it. Here the independent variable was social assistance and was divided into two variables as formal and informal social assistance. So this study selected the EPF, ETF, Fisherman's pension scheme, Farmer's Pension Scheme to measure the FSA Menike (2015); Arunathilake \& Jayawardena (2010); Perera (2011). Informal social assistance measured through the question based on the theoretical definitions of Jones \& Vetter (1985); Ragobur \& Kasseah (2018); Kaluagekar (2007) and seven points adopted the Likert scale to measure it.

The data set was divided into two based on the answers related to the informal and formal. Analyzed separately using Partial Least Squares-Structural equation modeling (PLSSEM) because of these, the study attempted to evaluate the comparison between the social security of both formal and informal sector elders in Sri Lanka. The PLS-SEM helped to examine the interrelationship between multiple independ- ent and dependent variables to evaluate the relationship between more than one construct simultaneously. Assessing the reliability and validity test to enhance the reliability of the construct for made variables and efficiency of the structural model was evaluated by multicollinearity issues $\mathrm{R} 2$, effect size F2, and predictive relevance Q2.

Qualitative data were gathered having in-depth interviews with 6 elders (three elders from the informal sector and three elders from the formal sector) and qualitative data were analyzed using qualitative content analysis. The interview was composed of three main questions and twenty sub-questions. To keep participants' identities confidential, each participant had been represented using the "Case" accompanied by a number from 1 to 6 (Case1, Case 2 ...... Case 6). Qualitative content analysis was used to analyze the qualitative data.

\section{RESULTS}

The PLS-SEM method was used to analyze the collected data and it concluded under two steps. First, the outcomes of the outer model, and second, the outcomes of the inner model. In analyzing the data SMART PLS (Version 3) and SPSS (Version 21) were used. Finally, it was measured the overall model fit, validity and reliability, latent variable correlation, and testing the significance of the hypotheses constructed by the study. Descriptive statistics were employed to represent the description of the study sample. Mean, Median, Mode, Standard deviation, Skewness, Kurtosis were calculated using the data according to the dependent and independent variables which were proposed in this study. According to the descriptive results shows, all variables had a mean of zero and a standard deviation close to 1 . That means, this situation shows in the standard normal distribution, called a bell shape. So it can be concluded that the data distribution was normal. The skewness of the distribution of social security, SN, SC, HS, ES in the formal and informal sector was negatively skewed. That meant the scores stayed at the right end of the left end. On the other hand, formal social assistance in the formal sector and ES in the informal sector got positive values in skewness. That means scores stayed at the left end of the scale and spread out gradually to the left end. Most of the results of kurtosis were less than 3.5 , the nature of the variables in the distribution called platykurtic. All the median values were positively distributed.

Based on the PLS-SEM model, the study initially examined the six latent variables consisted of one dependent variable (social security) and five independent latent variables (FSA, $\mathrm{SC}, \mathrm{SN}, \mathrm{ES}, \mathrm{HS}$ ). First, we calculated the reliability and validity of every independent and dependent variable dividing the data set into two as answers related to the formal sector and informal sector. Two steps were followed to ensure the reliability and validity of the measurement model. In the first step calculated validity and the reliability scores between the questionnaire items and the lower construct of the dependent variable (first-order analysis). This study adopted two reliability and two validity tests. Table 1 shows standard factor loadings (for dependent variable) which were above the minimum criterion 0.7 confirming the indicator reliability and factor loggings were significant at 0.05 significance level (approved indicator reliability) (Henseler, Ringle, \& Sinkovics, 2009), and significant at t-statistic values at 0.05 confidence level. So, both test shows the model has higher reliability in constructs. 
Table 1: Analysis of the First-order Construct Indicator Reliability

\begin{tabular}{|c|c|c|c|c|}
\hline & Formal Sector & & Informal Sector & \\
\hline Questionnaire Item & Outer Loadings & T-statistic & Outer Loadings & T-statistic \\
\hline \multicolumn{5}{|l|}{ Health Care } \\
\hline $\begin{array}{l}\text { How do you rate service for elders in General Hospital in } \\
\text { your area? }\end{array}$ & - & - & 1.000 & 0.00 \\
\hline $\begin{array}{l}\text { How about the support from family members to overcome } \\
\text { your chronic illness? }\end{array}$ & 0.908 & 27.73 & - & - \\
\hline $\begin{array}{l}\text { Can you get your medicine at a time without any diffi- } \\
\text { culty? }\end{array}$ & 0.911 & 28.46 & - & - \\
\hline \multicolumn{5}{|l|}{ Income security } \\
\hline Can you get financial support from your family members? & 0.863 & 25.18 & 1.000 & 0.00 \\
\hline $\begin{array}{l}\text { Do you have enough savings or any other finical assets to } \\
\text { use in an emergency? }\end{array}$ & 0.872 & 26.17 & - & - \\
\hline $\begin{array}{l}\text { Do you have financial support from the neighbors or any } \\
\text { other non-government organization? }\end{array}$ & 0.906 & 44.05 & - & - \\
\hline
\end{tabular}

$\mathrm{N}=149$, Source: Survey data, 2020

According to Table 2, results confirm the internal consistency and reliability Cronbach's alpha (CA) and Composite Reliability (CR) show all values are above in minimum thresh- old value 0.7 (Devellis, 1991). It shows higher internal consistency with all the indicators in the first-order analysis (Table 2).

Table 2: First-order Internal Consistency and Convergent Validity

\begin{tabular}{lcrrrrr}
\hline & \multicolumn{2}{c}{ Internal Consistency } & \multicolumn{3}{c}{ Convergent validity } \\
\cline { 2 - 7 } & \multicolumn{2}{c}{ Formal sector } & Informal Sector & Formal Sector & \multicolumn{2}{l}{ Informal Sector } \\
\cline { 2 - 7 } & CR & CA & CR & CA & AVE & AVE \\
\hline Health & 0.906 & 0.792 & 1 & 1 & 0.828 & 1 \\
\hline Income & 0.912 & 0.855 & 1 & 1 & 0.776 & 1 \\
\hline
\end{tabular}

$\mathrm{N}=149$, Source: Survey data, 2020

According to the validity test, the discriminant validity and convergent validity were calculated. Tables 3 and 4 show discriminant validity for all variables. It shows that all bold
(Square roots of all AVE values) are higher than the non-bold values, so discriminant values of the construct can be established for the first-order analysis (Fornell \& Lacker, 1981).

Table 3: Discriminant Validity of First-order constructs in formal and informal Sector (Fornell-Larcker Criterion)

\begin{tabular}{lcccc} 
& Formal Sector & & Informal Sector \\
\cline { 2 - 5 } Health & Health & Income & Health & Income \\
\cline { 2 - 5 } & 0.910 & - & 1 & - \\
\hline Income & & & & \\
\hline
\end{tabular}

Source: Survey data, 2020

The second step carried out reliability and validity tests between lower and higher constructs (second-order analysis). Same as the previous step done by the reliability and validity test for the final model. It measured the indicator reliability (outer loadings, T- statistic) and internal consistency reliability (Composite reliability, Cronbach's alpha) calculated between the indicator and questionnaire items using the convergent validity (AVE) and Discriminant validity (FornellLacker criteria). According to Table 4, the results confirm the indicator reliability of the second-order analysis. All outer loading values are greater than the 0.7 (approved indicator reliability) (Henseler, Ringle, \& Sinkovics, 2009) and significant at t-statistic values at the 0.05 confidence level. So, both test shows the model has higher reliability in constructs. Concern the internal consistency and reliability Cronbach's alpha (CA) and Composite Reliability (CR) shows all values are above in minimum threshold value 0.7 (Devellis, 1991) it shows higher internal consistency with all indicators (Table 5). 
Table 4: Analysis of the Second Order Construct Indicator Reliability

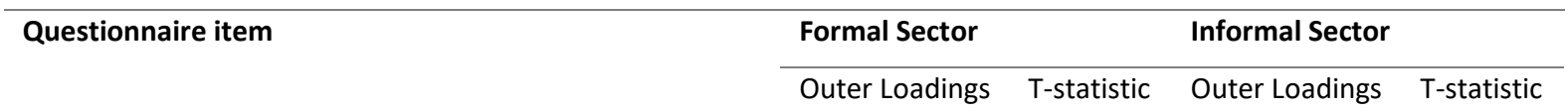

ETF, EPF, Government pension scheme/Fisherman pension scheme/Farmers pension scheme

How these schemes do sufficient to overcome your ex- 0.815

penditure

\begin{tabular}{|c|c|c|c|c|}
\hline Can you get those benefits timely? & 0.715 & 8.33 & 1.000 & 0.000 \\
\hline $\begin{array}{l}\text { What is your idea about the legal and ethical conditions } \\
\text { in these schemes? }\end{array}$ & 0.832 & 23.00 & - & - \\
\hline $\begin{array}{l}\text { What is your idea about the cost when you were bare for- } \\
\text { get this benefit? }\end{array}$ & 0.743 & 7.46 & - & - \\
\hline What is your idea about the availability of these schemes? & 0.721 & 8.02 & - & - \\
\hline \multicolumn{5}{|l|}{ Social connectedness } \\
\hline $\begin{array}{l}\text { How about your relationship with your children/ } \\
\text { friends/Neighbors? }\end{array}$ & 0.857 & 10.26 & - & - \\
\hline $\begin{array}{l}\text { How about your participation in community services and } \\
\text { religious activities? }\end{array}$ & 0.801 & 9.634 & - & - \\
\hline $\begin{array}{l}\text { Do you have a close relationship with neighbors or family } \\
\text { members to discuss your problems with them? }\end{array}$ & 0.930 & 15.04 & - & - \\
\hline \multicolumn{5}{|l|}{ Social network } \\
\hline $\begin{array}{l}\text { How far you satisfied with the necessities provided by } \\
\text { your family? }\end{array}$ & 0.815 & 9.629 & 0.932 & 3.731 \\
\hline $\begin{array}{l}\text { Do you have financial remittances from your family or } \\
\text { neighbors? }\end{array}$ & 0.757 & 7.023 & 0.767 & 2.614 \\
\hline $\begin{array}{l}\text { Do you have help from your friends or neighbors during } \\
\text { your illness period? }\end{array}$ & 0.887 & 19.56 & 0.762 & 3.149 \\
\hline $\begin{array}{l}\text { Do you have daily interaction, a sympathetic inquiry from } \\
\text { your neighbors or relatives or friends? }\end{array}$ & 0.741 & 6.226 & - & - \\
\hline $\begin{array}{l}\text { Do you have enough strength to participate in the deci- } \\
\text { sion making in your family }\end{array}$ & 0.850 & 25.56 & - & - \\
\hline
\end{tabular}

Economic support during the emergency (gold, savings)

\begin{tabular}{llll}
\hline $\begin{array}{l}\text { Do you have a fixed deposit or savings except for any } \\
\text { other financial allowance? }\end{array}$ & 0.894 & 28.486 & - \\
\hline How about your financial assets like Gold, Jewelry, etc.? & 0.885 & 27.418 & 0.954 \\
\hline $\begin{array}{l}\text { Can you get financial support from your friends, neigh- } \\
\text { bors, or children when you are in an emergency }\end{array}$ & 0.885 & 37.00 & - \\
\hline $\begin{array}{l}\text { During an emergency can you get benefit easily from } \\
\text { these assets }\end{array}$ & 0.924 & 56.66 & - \\
\hline $\begin{array}{l}\text { Can you get loans or insurance benefits when you are in } \\
\text { an emergency? }\end{array}$ & 0.777 & 189 & - \\
\hline
\end{tabular}

Health care support(care, treatment, and medicine)

\begin{tabular}{|c|c|c|c|c|}
\hline $\begin{array}{l}\text { How do you rate your current health support from rela- } \\
\text { tives, friends, or children? }\end{array}$ & 0.898 & 39.748 & - & - \\
\hline $\begin{array}{l}\text { Do you have daily interaction or special care from your } \\
\text { relatives, friends, or children to your illness? }\end{array}$ & 0.932 & 37.101 & 0.869 & 3.248 \\
\hline $\begin{array}{l}\text { Can you get financial support from your relatives or chil- } \\
\text { dren to purchase your medicine? }\end{array}$ & 0.909 & 38.708 & 0.914 & 3.437 \\
\hline $\begin{array}{l}\text { Can you get daily meals, special nutrition food from your } \\
\text { relatives or neighbors? }\end{array}$ & 0.897 & 38.34 & 0.889 & 3.386 \\
\hline $\begin{array}{l}\text { When you are in hospitalize can you get help to fulfill your } \\
\text { needs? }\end{array}$ & 0.873 & 19.22 & 0.886 & 3.296 \\
\hline
\end{tabular}

Source: Survey data, 2020 
Table 5: Internal Consistency and Convergent Validity

\begin{tabular}{|c|c|c|c|c|c|c|}
\hline & Internal Consi & & & & Convergent val & dity \\
\hline & Formal & & Informal & & Formal sector & Informal sector \\
\hline & $\mathrm{CR}$ & CA & CR & CA & AVE & AVE \\
\hline Health & 0.906 & 0.792 & 1 & 1 & 0.828 & 1 \\
\hline Income & 0.912 & 0.855 & 1 & 1 & 0.776 & 1 \\
\hline FSA & 0.876 & 0.825 & 1 & 1 & 0.588 & 1 \\
\hline SN & 0.906 & 0.873 & 0.863 & 0.906 & 0.659 & 0.679 \\
\hline SC & 0.898 & 0.834 & - & - & 0.747 & - \\
\hline HS & 0.898 & 0.834 & 0.938 & 0.915 & 0.814 & 0.792 \\
\hline ES & 0.942 & 0.922 & 0.950 & 0.895 & 0.765 & 0.904 \\
\hline
\end{tabular}

Source: Survey data, 2020

Concern about the validity test for Second-order scores greater than 0.5 confirms the convergent validity of the construct. So the entire model has higher convergent validity. Table 6 and Table 7 show discriminant validity for all variables. It shows all bold (Square roots of all AVE values) are higher than the non-bold values, so discriminant values of the construct can be established in the second analysis (Fornell \& Lacker, 1981).

Table 6: Discriminant Validity of Second-Order Constructs in the Formal Sector (Fornell-Larcker Criterion)

\begin{tabular}{lllllll}
\hline & ES & Formal SA & HS & SC & SN & Social Security \\
\hline ES & $\mathbf{0 . 8 7 4}$ & & & & & \\
\hline FSA & 0.609 & $\mathbf{0 . 7 6 7}$ & & & & \\
\hline HS & 0.791 & 0.630 & $\mathbf{0 . 9 0 2}$ & & & \\
\hline SC & 0.394 & 0.188 & 0.477 & $\mathbf{0 . 8 6 4}$ & & \\
\hline SN & 0.629 & 0.454 & 0.737 & 0.735 & $\mathbf{0 . 8 1 2}$ & 0.912 \\
\hline Social Security & 0.766 & 0.650 & 0.796 & 0.382 & 0.575 & \\
\hline
\end{tabular}

Source: Survey data, 2020

Table 7: Discriminant Validity of Second-Order Constructs in Informal Sector (Fornell-Larcker Criterion)

\begin{tabular}{llllll}
\hline & EC & Formal SA & HS & SN & Social Security \\
\hline ES & 0.951 & & & & \\
\hline FSA & -0.050 & 1 & & & \\
\hline HS & -0.091 & -0.093 & 0.890 & 0.824 & \\
\hline SN & -0.090 & -0.045 & 0.582 & -0.286 & 0.764
\end{tabular}

Source: Survey data, 2020

The study checked the collinearity issue (Haire, Sarstedt, Pieper, Ringle 2012) between the variables. Multiple regression in the SPSS (Version 21) is used to calculate the Variation Inflation Factor and Tolerance values for the multicollinearity issue. The VIF values for the formal sector show minimal collinearity, ranging from 1.826 to 3.849 . These values are significantly less than the recommended threshold values of 5.00. The tolerance value for the informal sector lies between 0.255 and 0.548 exceeding the minimum threshold value of 0.2 (Hair, Sarstedt, Hopkins, Kappelwieser 2011).
The VIF values for the informal sector show minimal collinearity, ranging from 1.012 to 1.529 . These values are significantly less than the recommended threshold value of 5.00. The tolerance values for the informal sector lie between 0.659 and 0.986 . These values are exceeding the minimum threshold value of 0.02 (Hair, et al., 2011). After that examine the significance and relevance of the structural equation model. After that checked hypothesis was constructed between the dependent and independent variables.

Table 8: Assignment of the significance and relevance of the structural model relationships

\begin{tabular}{lll}
\hline Hypothesis & Formal Sector & Informal Sector \\
\cline { 2 - 4 } & $\begin{array}{l}\text { Path coef- } \\
\text { ficient (B) }\end{array}$ & $\begin{array}{l}\text { Path coeffi- } \\
\text { cient (ß) }\end{array}$ \\
\hline
\end{tabular}




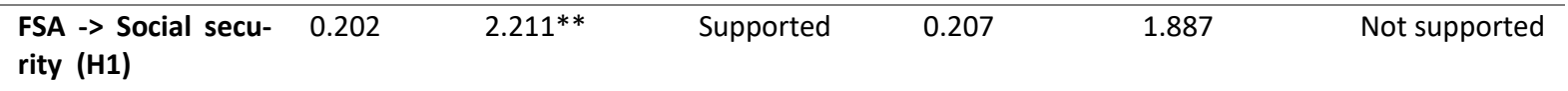

\begin{tabular}{lllllll}
\hline $\begin{array}{l}\text { SC }->\text { Social security } \\
\text { ( H2) }\end{array}$ & 0.090 & 1.009 & Not Supported & - & - & - \\
\hline $\begin{array}{l}\text { SN }->\text { Social security } \\
\text { ( H3) }\end{array}$ & -0.130 & 1.085 & Not supported & -0.129 & 0.882 & Not supported \\
\hline $\begin{array}{l}\text { ES-> Social security } \\
\text { ( H4) }\end{array}$ & 0.316 & $2.984^{* *}$ & Supported & 0.383 & $3.539^{* *}$ & Supported \\
\hline $\begin{array}{l}\text { HS-> Social security } \\
\text { (H5) }\end{array}$ & 0.471 & $3.431^{* *}$ & Supported & -0.193 & 1.363 & Not supported \\
\hline
\end{tabular}

Source: Survey data, 2020

**P $>0.05$

\section{DISCUSSION}

According to Table $8, \beta$ coefficient of formal social assistance is 0.202 which is a higher significance path coefficient value of 0.01 also t-stat higher than 1.96 at 0.05 significance level ( $t$-stat $=2.211$ ) and it can be exhibited as there is a significant relationship between social security and FSA regarding the formal sector. It means that FSA increased by 1 percent social security of elders' increased by 20.27 percent. So it is suggested that there is a positive relationship between the FSA and the social security of elders regarding the formal sector. Out of six cases, four of them agreed on FSA's impact on the social security of the elders in the older age. Three of them were employed in the formal sector and another one was employed in the informal sector. Another two of them agreed with the same, but they said it should not be adequate to overcome their daily expenses. In that case, most of them were engaged in the informal sector. The outcomes of the study were in line with the theoretical and empirical literature. Crawford \& Lilien (as cited in Sanita, Parida \& Pattyat, 2019) said most elders in the labour force were eligible to receive formal social security benefits which contributed to the major part of their salary. So the researcher found that these results supported FSA strongly proved hypothesis $\mathrm{H} 1$ regarding the formal sector. That means this scheme helps to fulfill their expenditure, availability, and timely benefit to the formal sector workers.

On the other hand, the FSA of informal sector path coefficient value is 0.207 , which can be exhibited as there is a significant relationship between social security and social assistance regarding the informal sector. That means FSA increased by 1 percent social security of elders increased by 20.79 percent. However, the t-stat value of the FSA in the informal sector was recorded as 1.887 which indicates lower than the minimum threshold value of 1.96 under 0.05 significant level. Further, it explained that it positively affected the increase in the social security of elders in the formal and informal sectors. Out of these six case studies, formal sector respondents revealed that they had sufficient and satisfying service through FSA. In the above Table 10 shows the responses "Very good" for all five questionnaire items for the FSA dimension. Further, an FSA like EPF, ETF schemes had highly affected them to fulfill their higher amount of medical bills; Cardiac and Diabetes surgeries. Some of them said it was very useful for them to do their work without financial help from their children. Specifically, they mentioned that their financial stability indirectly supported their children to reduce their expenses for their parents. But, considering the social and cultural beliefs, we have the responsibility to give care to our parents when they become elders. However, informal sector elders said (case 6);
"These schemes were not enough to fulfill our expenses. On the other hand, the government didn't pay considerable attention to our needs and wants after we will become disabled or injured. That is the major issue for people like us."

They mainly pointed out that the Farmer's and fishermen's schemes had good characteristics. But, these were not developed according to the current situation of social and economic changes. So these schemes were inadequate to overcome formal care for informal sector elders in Sri Lanka. Moreover, those schemes are not significant with the social security of elders in the informal sector, and the above responses are curiously affected in rejecting hypothesis $\mathrm{H} 1$ regarding the informal sector. According to Van (1999) who can't overcome policies for productive employment and who can't contribute to the self-financed social insurance schemes (informal sector workers) can positively affect for FSA scheme to improve their social security in older age. Dethier (2007) said that social insurance (Formal social security) denotes mandatory contributory programs to cover major life risks such as health risks in old age. According to Eriyagama \& Rannan-Eliya (2003) sometimes they can suffer from lifelong disabilities and injuries because of their fieldwork. So considering this situation these schemes would provide disability benefits, disablement gratuity, and death gratuity to the person if enlisted in this scheme. Thus, the qualitative results prove the results found by the quantitative study.

Case 1 said that,

"Government pension scheme was very much important for us to protect our older age".

Case 2 said that the government pension scheme was very important to him to enhance social security when they were retired. Further, he explained that the government pension scheme is the major income source in their home. He said that it was enough to overcome their health and income security in their old age. Case 4 said that a fisherman's pension scheme was not enough to overcome their social security. However, he said that it was enough to overcome some small expenses they had to bear daily. So $\mathrm{H} 1$ hypothesis was not accepted regarding the informal sector although there were some similar studies done by previous researchers that provide evidence from their findings. Kohli, et al., (2018) said old-age pension schemes in India significantly impacted the increase in the social security of elders in India. Gaminirathna (2004) explained that strengthening the formal social security in the informal sector was very much important to the Sri Lankan economy because 64 Percent of workers engaged as informal sector workers. According to ILO (2001), in Brazil, the social assistance pension scheme caused to 
eradicate extreme poverty from $14 \mathrm{MN}$ elders in their country.

According to the path coefficient of ( $\beta$ value) of social connectedness in the formal sector was 0.090 which was lower than the standard path coefficient value and the t-statistic value represents 1.009 at 0.05 level of significance which was lower than 1.96 at 0.05 significance level. Further, it shows a positive relationship with the social security of elders in the formal sector. That means when social connectedness is increased by 1 percent the social security of the elders is increased by 9 percent. However, it does not support accepting the $\mathrm{H} 2$ hypotheses because it does not include the given acceptance criteria. On the other hand, SC has not impacted the social security of elders in the informal sector. Out of six cases, all of them agreed on SC impacted the social security of the elders in older age. Three of them were employed in the formal sector and another two persons were employed in the informal sector. However, some of them said it should not be adequate to overcome social security in old age. The qualitative outcomes of the study are in line with the theoretical and empirical literature. Moreover, Table 10 shows the average satisfaction level of the formal sector workers who gives "Good" for each question under social connectedness. In the informal sector, the elders gave the average level of satisfaction as "Very good". The reason for this phenomenon we can consider as higher scores of satisfaction occur when they have a good connection with their relationships. Some of them said (case 1)

"We have no enough time to build a relationship with our neighbor. Because we were very busy with our works in the past years. However, we think that type of relationships and activities must be helpful to increase our mental health rather than physical health"

Case 2 said, SC caused to help their everyday life and it indirectly supported to increase their mental and physical health. Most of them (case 2, case 3, and case 4) received help from their children and relatives, and neighbors. Some of them (case 6) get their everyday meals from their neighbors. In reality, we can say SC is very much important to increase the social security of elders in Sri Lanka. According to Zaho, et al., (2020), the SC was the main dimension of informal social care. They said that the breakdown of the SC due to urbanization may cause to weaken the kinship and friendship among the elders' community. Asanta \& Castillo (2018) revealed that SC depended on network size and satisfaction with the network. Emlet \& Moceri (2012) explained that social connectedness has a positive impact on creating strong social ties to the elderly-friendly community.

According to the path coefficient of the social network in the formal and informal sector is higher than the minimum threshold value of 0.01 and t-statistic value represent the 1.085 and 0.88 at the significant level of 1.96 for formal and informal sector respectively. These values are not significant at the 0.05 level and it shows a negative impact on the social security of elders. According to the theoretical, empirical, and qualitative results, the SN has a positive impact on the social security of elders. Out of six cases, all of them agreed with the impact of SN on the social security of the elders in the older age. Three of them were employed in the formal sector. The outcomes of the qualitative study are in line with the theoretical and empirical literature.

According to Grucia, et al., (2005), SN means the web of social relationships surrounded an individual and characteristic of social ties. Further, they explained that social support did mediate the role of the relationship between the $\mathrm{SN}$ and health. According to Pinquart \& Sorensen (2000), the network and subjective well-being in later life (social security of elders) had a positive relationship with the social security of elders. Kaulagekar (2007) implies that daily interaction, sympathetic care are the most important and positive impacts on the social security of elders.

Cases 1, 2, 5 said that they had a good SN relationship with their community. Further, they explained that they received help from their friends or neighbors during their illness periods, they had daily interaction, a sympathetic inquiry from their neighbor's relatives or friends. Finally, they were satisfied with the necessities provided by their family. On the other hand, 4 mentioned that he had not enough time to make the best relationship with their neighbors because he had a busy life before he retired. But he said that his family and neighbors very much supported his work after he was retired. However, the $\mathrm{H} 3$ hypothesis is not accepted under the quantitative results but it can be accepted under the qualitative results of the study.

According to the $\beta$ coefficient of ES is 0.316 which is a higher significance path coefficient value of 0.01 also t-stat higher than 1.96 at 0.05 significance level $(\mathrm{t}$ - stat $=2.984$ ) and it can be exhibited as there is a significant relationship between social security and ES regarding the formal sector. That means the increase of ES by 1 percent increases the social security of elders by 29.84 percent. So it is suggested that there is a positive relationship between the ES and social security of elders regarding the formal sector. So the researcher found that these results supported ES strongly proved hypothesis $\mathrm{H} 4$ regarding the formal sector. That means that they have enough savings, other financial assets, and help from their children during an emergency. On the other hand, ES of informal sector path coefficient value is 0.383 , it can be exhibited as there is a significant relationship between social security and social assistance regarding the informal sector and t-stat is higher than 1.96 at 0.05 significance level ( $t$ - stat $=3.53$ ). That means that the increase of ES by 1 percent increases the social security of elders by 38.30 percent. So it is suggested that there is a positive relationship between the ES and social security of elders regarding the informal sector. So the researcher found that these results supported ES strongly proved hypothesis $\mathrm{H} 4$ regarding the informal sector although there were some similar studies done by previous researchers provided findings. Ruparanganda, et al., (2018) said that the ES in emergency conditions was very much important to the elders in the formal and informal sectors. According to the qualitative content analysis, all the cases highly agree about the support from their children and another relative when they were facing emergency conditions. Specifically, they said, that their children and relatives gave financial support during this kind of situation. Table 10 shows different answers for this dimension than another dimension. Under that, most of them gave "Fair" for all the questions asked for social connectedness. They mentioned they had good support from the children in this kind of situation like sudden illness. Cases 1 and 3 prove it through this statement;

"We had good support from our children, neighbors, or relatives from this kind of situation"

"We had no savings or gold assets to use for getting money to face sudden incidences. At that time our children and neighbors give their full support for us to overcome it"

However, they said they have no savings or insurance benefit when they become older age and formal sector workers mention they have no support from any other sources to 
overcome their wants and needs in this kind of situation. Finally, we can conclude informal care is very much important to enhance the social security of elders in Sri Lanka.

According to the $\beta$ coefficient, HS is 0.471 which is a higher significance path coefficient value of 0.01 also t-stat higher than 1.96 at 0.05 significance level ( $t$ - stat $=3.431$ ) and it can be exhibited as there is a significant relationship between social security and HS regarding the formal sector. That means HS is increased by 1 percent the social security of the elders is increased by 47.12 percent. So it is suggested that there is a positive relationship between the HS and social security of elders regarding the formal sector. So the researcher found that these results support HS's strongly proved hypothesis $\mathrm{H} 4$ regarding the formal sector. That means they have adequate HS from their family and other relatives. However, the HS of informal sector path coefficient value is -0.193 which can be exhibited as there is a significant relationship between social security and HS regarding the informal sector. But it should exhibit a negative relation and the t-statistic value (1.363) is less than the 1.96 at 0.05 significance level. So H5 hypothesis is not accepted regarding the informal sector although there are some similar studies done by previous researchers that provide findings. Dai (2015) said that health security in old age people in China had a positive impact on the social security of elders. According to Perera (2011), HS is very much important to Sir Lankan society because they have a higher elderly population rate. Out of six cases, all of them agreed on the impact of health care support on the social security of the elders in old age. Three of them were employed in the formal sector. The outcomes of the qualitative study are in line with the theoretical and empirical literature. Further, case 5 said;

"Our family members gave good support for me to enhance my health conditions and gave their daily attention to my medicine and gave more attention to my foods"

So HS is very significant for increasing the social security of elders in Sri Lanka. Kaulagekar (2007) investigated the availability of social support to the elders when they would become older. Kinship, neighbor involvement to the health care, support, and care during the illness periods are some major dimensions for informal social assistance such as providing daily meals, cooking food from their kitchen, provide food and vegetables and fetching water, take care from the hospitalized periods. Shiba, Kondo \& Kondo (2016) said family members' supports were very effective for emotional support during old age.

Case 1, 2, 4 said they had a good health condition and they had good support from their family members and relatives. They mentioned most of the time they got their medicine from private hospitals because family members pay their bills and they gave more attention to the good caring for their parents. On the other hand, relatives and neighbors' involvement in health care during the illness periods. According to this study R2 for the formal sector is recorded as 0.71 . That means the social security of elders in the formal sector is explained by 71 percent by the five independent variables as social assistance. Generally, it considers a higher strong effect on the dependent variable (Alhyari, 2016). However, 29 percent of the social security of elders is not explained by the five dimensions of social assistance. The R2 for the formal sector is recorded as 0.29 . That means the social security of elders in the formal sector is explained by 29 percent by the five independent variables as social assistance. However, 71 percent of the social security of elders is not explained by the five dimensions of social assistance.
Generally, it considers a lower effect on the dependent variable (Alhyari, 2016). Considering the F2 values, the FSA of the formal sector is 0.27 while the informal sector is 0.25 . That means FSA has a small effect size. SC has a large effect size for social security regarding the formal sector recorded as 0.5 . The value of $F 2$ of the $\mathrm{SN}$ is 1.313 for the formal sector and 0.188 for the informal sector. That means the SN has a large effect size with the social security of elders in the formal sector and a small effect size with the informal sector. F2 value ES has a 1.944 effect size for the formal sector and 0.292 for the informal sector. That means the formal and informal sectors have a large and medium effect size with social security. F2 value for HS is 0.917 and 0.3519 for social security elder's formal and informal sector respectively. That means it has a large and medium effect size for HS for social security of elders in the formal and informal sectors.Q2 value of 0.58 in the formal sector and predictive relevance for social security in the informal sector is 0.13 . That means the formal and informal sectors have large and medium predictive relevance for the social security of elders in this study.

\section{CONCLUSION}

Currently, though the farmers have some traditional CSA practices, the modern CSA practices are not in action in the Karuwalagaswewa DSD in Puttlam district. Hence, to The results of the study reveal that the ES of both formal and informal sectors positively impacts the social security of elders in the formal and informal sectors. This significant positive relationship of ES on social security of elders realize that both formal and informal sector elders can get help from their children, relatives, and neighbors to enhance their social security conditions. Further, this result reveals that both formal and informal sector elders in Sri Lanka have good care from informal social assistance than all social assistance. That means formal social security schemes were not enough for them to fulfill needs and wants in older age. On the other hand, qualitative results show very satisfactorily for real care about the formal and informal sector elders. Out of six cases, they said that most of the time they had good support from their social contacts. Moreover, this study shows that FSA dimensions concerning the formal sector have the highest positive relationship with the social security of elders. However, these dimensions are statistically insignificant to determine social security regarding the informal sector. So this result implies that the government pension scheme is enough to fulfill their social security conditions when they are older. And also government pensioners can get this benefit easily and regularly. Because it is financed through the government budget. On the other hand, pensioners in the private sector can get ETF, EPF funds after their retirement. That funds give onetime huge payment after their retirement. So these formal social security schemes are very much supportive of overcoming the social security problems they face after they retired.

Further, HS dimensions with regards to the formal sector have the highest positive relationship with regards to the social security of elders. However, this variable is statistically insignificant with the informal sector. So this result implies that formal sector elders have good care and medical treatments from their family members. According to the qualitative results HS was significant with both formal and informal sector elders. Specifically, informal sector elders said they had good support from their children to get medicine and other essential treatments. Moreover, a qualitative study 
shows that social network relationships have a significant relationship with the social security of elders in both sectors. Out of six cases they said, they had good social network relationships while they could do their work properly and regularly. The findings of the study can identify the need for more informal care than formal care in both sectors and more formal care for the informal sector workers after they retired from their employment.

In Sri Lanka inadequately pay attention to informal care problems to solve our future demographic challenge. When the population arises, this research finds country wants significant attention to the formal and informal social assistance to the elders in the formal and informal sectors. The main implication of this study is FSA and informal social assistance impact the increasing social security of elders in the formal sector. FSA does not impact the increase in the social security of elders in the informal sector. Further, informal social assistance in the informal sector elders has an impact on the increase in social security in old age. Finally, the findings of this study will affect the current younger generation to get a better decision to their social security condition when they become elders. On the other hand, this study identifies the research problem through qualitative findings. Moreover, this study shows informal social care is important than formal social care for elders to sustain their last part of life.

\section{REFERENCES}

Adzawla, W., Baanni, S. A., \& Wontumi, R. F. (2015). Factors influencing informal sector workers' Strategy, 5(2), 37-45

Alhyari, Salah. (2016). Re: What is the acceptable R-squared in the information system research? Can you provide some references? Retrieved from:https://www.researchgate.net/post/What_is_the_acceptable_Rsquared_in_the_information_system_research_Can_you_provide_some_references/569cf1be6225ff80618b4578/citation/download

Aluko, Yetunde. (2007). Old-Age and Social Security in Nigeria: The Challenges of the New World Order. International Journal of Social and Management Sciences. 1. 73-87.

Central Bank of Sri Lanka, 2020. Annual report of Central Bank of Sri Lanka 2019, Central Bank of Sri Lanka.

Arunatilake, Nisha \& Jayawardena, Priyanka. (2010). Why people choose to participate in the informal sector in Sri Lanka. Indian Journal of Labour Economics. 53. 225-249.

Arunatilake, Nisha \& Jayawardena, Priyanka. (2010). Why people choose to participate in the informal sector in Sri Lanka. Indian Journal of Labour Economics. 53. 225-249.

Asante, S., \& Castillo, J. (2018). Social connectedness, perceived socia support, and health among older adults. InnovationinAg ing,2(Suppl1),737. https://doi.org/10.1093/geroni/igy023.2719

Cousins, M. (2007). Social Security, Social Assistance, and Special NonContributory Benefits': The Never-Ending Story. European Journal of Social Security, 9(1), 95-106.

Dai B. (2015). The old-age health security in rural China: where to go? International journal for equity in health, 14, 119 https://doi.org/10.1186/s12939-015-0224-5

Dai, Y., Zhang, C. Y., Zhang, B. Q., Li, Z., Jiang, C., \& Huang, H. L. (2016) Social support and the self-rated health of older people: A comparative study in Tainan Taiwan and Fuzhou Fujian province. Medicine, 95(24), 108-126.

De Silva (2012), "The age structure transition and the demographic dividend: An opportunity for rapid economic take-off in Sri Lanka", Sri Lanka Journal of advanced social studies, 2(1), 3-46.

Dethier, Jean-Jacques. (2007). "Social Security: What Can Developing Countries Learn from Developed Countries?" 7.

DeVellis, R. (1991). Scale development: theory and applications. Newbury Park: Sage.
Emlet, C. A., \& Moceri, J. T. (2012). The importance of social connectedness in building age-friendly communities. Journal of aging research, 4(2), 91-114.

Eriyagama, V., \& Rannan-Eliya, R. P. (2003). Assessment of the Farmers' and Fishermen's Pension and Social Security Benefit Scheme Facts on social security, International Labour Organization.

Frausto, S. R. (2001). Population Ageing in the Mexican Institute of Social Security: Health Policy and Economic Implications. Instituto Mexicano del Seguro Socia.

Gaminiratne, N. (2004). Population aging, elderly welfare, and extending retirement cover: The case study of Sri Lanka. London: Overseas Development Institute.

García, E. L., Banegas, J. R., Perez-Regadera, A. G., Cabrera, R. H., \& Rodriguez-Artalejo, F. (2005). Social network and health-related quality of life in older adults: a population-based study in Spain. Quality of life research, 14(2), 511-520

Goswami, S., Köbler, F., Leimeister, J. M., \& Krcmar, H. (2010, June). Using online social networking to enhance social connectedness and social support for the elderly. Association for Information Systems.

Hair, J., Sarstedt, M., Hopkins, L., \& Kuppelwieser, V. (2014). Partial least squares structural equation modeling (PLS-SEM): An emerging tool in business research. European Business Review, 26(2), 106-121.

Hair, J., Sarstedt, M., Pieper, T., \& Ringle, C. (2012). The use of partial least squares structural equation modeling in strategic management research: A review of past practices and recommendations for future applications. Long Range Planning.

Hellström, Y., \& Hallberg, I. R. (2001). Perspectives of elderly people receiving home help on health, care, and quality of life. Health \& Social Care in the Community, 9(2), 61-71.

Henseler, J., Ringle, C., \& Sinkovics, R. (2009). The use of partial least squares path modeling in international marketing. New Challenges to International Marketing (Advances international Marketing, 20(2), 227-231.

Jones, D., \& Vetter, N. (1985). Formal and Informal Support Received By Carers of Elderly Dependants. British Medical Journal (Clinical Research Edition), 291(6), 643-645. Retrieved June 6, 2020, from www.jstor.org/stable/29520485

Justino, Patricia. (2007). "Social Security in Developing Countries: MYTH or Necessity? Evidence from India." Journal of International Development 19(3):367-82

Karunarathne, W., \& Goswami, R. (2002). Reforming formal social security systems in India and Sri Lanka. International Social Security Review, 55(4), 89-106.

Kaulagekar, A. (2007). Aging and Social Support: A Study of Low-income Urban Elderly in Pune. Indian Anthropologist, 37(2), 45-53. Retrieved June 5, 2020, from www.jstor.org/stable/41920039

Kaushal, N. (2014). How public pension affects elderly labor supply and well-being: Evidence from India. World Development, 56, 214-225.

Kohli, C., Gupta, K., Banerjee, B., \& Ingle, G. K. (2017). Social security measures for the elderly population in Delhi, India: Awareness, utilization, and barriers. Journal of clinical and diagnostic research: JCDR, 11(5), LC10.

Menike, H. A. (2015). Social support and social security of the elderly population in Sri Lanka. International Journal of Business and Social Science, 6(11), 123-140.

Nguyen, Cuong. (2010). The Impact of Social Security on Household Welfare: Evidence from a Transition Country. European Journal of Development Research. 25. 10.1057/ejdr.2013.11.

Paraponaris, A., Davin, B., \& Verger, P. (2012). Formal and informal care for the disabled elderly living in the community: an appraisal of French care composition and costs. The European Journal of Health Economics, 13(3), 327-336.

Perera, Bilesha. (2011). "Social Support and Social Security Issues of Elders in Sri Lanka." Galle Medical Journal 16(2):20.

Perera, E. A. Y. D., \& Weerakkody, W. A. S. (2019). Determinants of PostRetirement Employment in Sri Lanka. Kelaniya Journal of Management, 7(2), 45-63.

Pinquart, M., \& Sörensen, S. (2000). Influences of socioeconomic status, social network, and competence on subjective well-being in later life: a meta-analysis. Psychology and Aging, 15(2), 18-31 
Pradeep M. D., and M. L. Kalicharan. 2016. "Social Security Measures For Indian Workforce - A Legal Intervention." Academic Journal of Business. Administration, Law and Social Sciences, 2(2). 74-92.

Ragoobur, Verena Tandrayen, and Harshana Kasseeah. 2018. "Informal Social Protection: A Case Study of a Small Island Economy." International Journal of Public Policy 14(5/6):391.

Ruparanganda, L., Ruparanganda, B., \& Mabvurira, V. (2018). The place of 'traditional social security in the modern era: Lessons from Buhera District. African Journal of Social Work, 8(1), 39-46

Sanitha, V. P., Parida, J. K., \& Pattayat, S. S. (2019). Structural transformation, population aging, and elderly labor force participation in Kerala, India. IASSI-Quarterly, 38(1), 59-88.

Serrano, J. P., Latorre, J. M., \& Gatz, M. (2014). Spain: Promoting the welfare of older adults in the context of population aging. The Gerontologist, 54(5), 733-740.

Shiba, Koichiro, Naoki Kondo, and Katsunori Kondo. (2016). "Informal and Formal Social Support and Caregiver Burden: The AGES Caregiver Survey." Journal of Epidemiology 26(12):622-28.

ShuHong, Y., Zia-ud-Din, M., \& Ranjha, K. M. (2017). Social Protection Schemes in Pakistan: assessment of existing programs. Academic Journal of Business. Administration, Law and Social Sciences, 3(2), 34 - 52.

Sinclair, T. J., \& Grieve, R. (2017). Facebook as a source of social connectedness in older adults. Computers in Human Behavior, 66, 363-369.

Tilakaratna, G. and S. Jayawardena (2015) 'Social Protection in Sri Lanka: Current Status and Effect on Labour Market Outcomes' SARNET working paper No. 3, South Asia Research Network.

Van Ginneken, Wouter. 1999. "Social Security for the Informal Sector: A New Challenge for the Developing Countries." International Social Security Review 52(1):49-69.

Woolard, I., Harttgen, K., \& Klasen, S. (2011). The history and impact of social security in South Africa: experiences and lessons. Canadian Journal of Development Studies, 32(4), 357-380.

Zhao, Z., Jing, S., Yan, Z., \& Yu, L. (2020). Social change and birth cohort decrease in social support for older adults in China: A cross-tempora meta-analysis, 1994-2018. Health \& Social Care in the Community. 
